\title{
Métodos de Extração e Atividade Antimicrobiana do Biossurfartante Produzido Por Bacillus subtilis- Atcc19659
}

Danielle de Almeida*, Cibele G. Bastos, Michel A. Amaral, Juliana T. de Magalhães, Adriano G. Parreira, Daniel B. Gonçalves, Fernanda S. Carvalho, José A. da Silva, Paulo A. Granjeiro

Curso de Bioquímica, Universidade Federal de São João Del-Rei, Divinópolis/MG *e-mail:dani_almeida45@hotmail.com

\section{Resumo}

Os biossurfactantes (BS) são compostos anfipáticos sintetizados por microrganismos capazes de reduzir a tensão superficial e interfacial (água e óleo), tornando-se um agente emulsificante de grande interesse industrial e alto valor agregado. Apresentam vantagens quanto aos surfactantes sintéticos, pois são biodegradáveis e exibem baixa toxicidade, levando a inúmeras aplicações, como na biorremediação, produção de cosméticos e desenvolvimento de novos agentes terapêuticos. O objetivo desse trabalho foi testar métodos de extração dos biossurfactantes produzidos por Bacillus subtilis (ATCC19659) visando melhor rendimento e purificação, realizar a caracterização da tensão superficial e avaliar o potencial antimicrobiano através da concentração mínima inibitória (MIC) e concentração mínima bactericida (MBC) em Escherichia coli (ATCC25992), Staphylococcus aureus (ATCC29213) e Staphylococcus epidermidis (ATCC12228). Após a melhor condição de cultivo foi realizada a precipitação ácida $(\mathrm{pH}=2,0)$, seguida de três diferentes métodos de extração por solventes orgânicos, como clorofórmio: metanol (65:15), acetato de etila:metanol (4:1) e diclorometano,obtendo-se $0 \mathrm{mg} / \mathrm{mL}, 17 \mathrm{mg} / \mathrm{mL}$ e $90 \mathrm{mg} / \mathrm{L}$ de biossurfactante, respectivamente. Para os dois melhores métodos de extração, onde se obteve os maiores rendimentos, o BS apresentou a mesma redução da tensão superficial de $72 \mathrm{mN} / \mathrm{m}$ (tensão superficial da água) para $42 \mathrm{mN} / \mathrm{m}$, na concentração de $500 \mu \mathrm{g} / \mathrm{mL}$. Os valores de MIC e MBC para a bactéria E. coli 
foi de $10 \mu \mathrm{g} / \mathrm{mL}$ e para $S$. aureus e $S$. epidermidis foi de $240 \mu \mathrm{g} / \mathrm{mL}$, confirmando a atividade antimicrobiana. Portanto, conclui-se que o BS apresentou o maior rendimento quando utilizado diclorometano e foi eficiente na redução da tensão superficial. A capacidade antimicrobiana demonstra aplicação industrial, com perspectiva tanto na atividade antiadesiva de biofilme quanto na terapêutica.

Palavras-chave: biossurfactante, extração, atividade antimicrobiana, bacillus subtilis.

Apoio financeiro: CNPq, FAPEMIG. 